\title{
Construction of a QCM Biosensor for free Hemoglobin Assay
}

\author{
Miroslav Pohanka \\ Faculty of Military Health Sciences, University of Defence, Trebesska 1575, CZ-500 01 Hradec \\ Kralove, Czech Republic \\ E-mail: miroslav.pohanka@gmail.com
}

doi: $10.20964 / 2019.06 .48$

Received: 5 Februay 2019 / Accepted: 9 March 2019 / Published: 10 May 2019

Protein responsible for oxygen transfer, hemoglobin, is an important marker in biochemistry that can be measured in blood and blood plasma. Meaning of the assays are different in the two fluids. While blood hemoglobin serving as a marker of anemia and some oncotic processes is simply measurable by spectroscopy, hemoglobin content in plasma, a marker of hemolytic processes, is significantly lower and the assay should be done by more elaborative techniques. In this paper, piezoelectric biosensor containing QCM platform with basic frequency of oscillations $10 \mathrm{MHz}$ and gold circle electrodes on the opposite sites, antibody against hemoglobin and iron oxide nanoparticles as blocker and antibody layer stabilizer was prepared. The assay exerted limit of detection equal to $0.063 \mathrm{mg} / \mathrm{ml}$ and the calibration well correlated $\left(r^{2}=0.995\right)$ with standard ELISA. No interference by immunoglobulins and albumin was proved. The assay appears to applicable for clinical praxis and outside of central hospital laboratories. Reasonably limit of detection, low price of the biosensor and device, simple procedure of sample use, no necessity of specific reagents and label free type of assay are the major advantages of the biosensor.

Keywords: affinity; antibody; biosensor; biorecognition; blood; erythrocyte; hemoglobin; immunochemistry; label free assay; piezoelectric; quartz crystal microbalance; QCM

\section{$\underline{\text { FULL TEXT }}$}

(C) 2019 The Authors. Published by ESG (www.electrochemsci.org). This article is an open access article distributed under the terms and conditions of the Creative Commons Attribution license (http://creativecommons.org/licenses/by/4.0/). 